than to the storing up of the materials of history. This first issue presents the following table of contents: "Joliet and Marquette in Iowa," by Laenas Gifford Weld; "The Political Value of State Constitutional History," by Francis Newton Thorpe; "Historico-Anthropological Possibilities in Iowa," by Duren J. H. Ward; "A General Survey of the Literature of Iowa History," by Johnson Brigham. Reviews. of various historical publications, "Notes and Comments," make up the remaining contents of the first number. This journal gives promise of long life and usefulness. It is under the editorial management of Prof. B. F. Shambaugh, whose writings and labors in the expanding field of Iowa history are well known throughout the country, and a sufficient guaranty of the permanence of this new candidate for the public favor. We welcome it to its field of usefulness with all good wishes for its long life and success. It is published quarterly at two dollars per year. Address the State Historical Society of Iowa, Iowa City, Iowa.

\title{
IS IOWA'S HISTORY WORTH WHILE?
}

One frequently observes in the writings of Iowa's chroniclers an underlying assumption-perhaps one should say presumption-that the history of our State is not especially worth while. This assumption is obvious in the general acquiescence in the notion commonly expressed in conversation that the history of Iowa is not particularly interesting or instructive, that our customs, laws and institutions are neither distinctive nor noteworthy, that our life and scenery are lacking in picturesqueness. In brief, "prosaic" and "matter-of-fact" are the descriptive terms usually applied to our people and to the history of our State.

All Iowans, of course, declare with venemence that Iowa is a magnificent State, that her citizens thrive wonderfully in industry, and her statesmen have played prominent roles in national affairs. But despite all this there is a willingness 
to admit that in the large and vital things that make a people great and their history interesting and worth study, we do not find much worth while in the chronicles of this western commonwealth. Not long since when a young literateur, after a few days sojourn among us, held our life and institutions up to the mirror in The Atlantic, and in descantingupon the reflections, unburdened himself of divers facetious lamentations over the vastness of the commonplace among us and the immeasureable dullness and mediocrity of our society, there was no denial, rather a resigned sort of acceptance of his verdict with some grimaces and shrugging of shoulders.

Now the correctness of this assumption depends upon the things in which we are interested and from which we seek instruction. We must first determine our point of view.

. If we seek and must have striking contrasts in local scenery, in social and economic conditions and institutions, we must admit that Iowa's history cannot furnish much that is strikingly picturesque or romantic. The State has no vast stretches of forests or wild and rugged mountainous regions that caused our early institutions to develop in peculiar directions. We cannot, as a result, lay claim to large districts inhabited by hordes of densely ignorant, superstitious, shiftless people, such as the Georgia "Crackers" or the Kentucky "Moonshiners." We have no large cities of ancient renown. The tales of our pioneers seldom mention Indian troubles or border wars of any description. We can boast of few, if any, hoary traditions or fantastic folk-lore that make our children shiver as the stories are told about the firesides. Our early history had but little of the rough and boisterous that has characterized the life of the plains and the mining camps of the Rockies. We have had no civil dissensions that have shaken the foundations of the state and wrenched and warped our institutions. In short he who must needs have heroics and great panoramic scenes, who craves accounts of bloodshed, wars and "seismic convulsions," tó use a phrase of an Iowa editor, will find but little to hold his attention. 
But if the spectacular, the war-like, the lurid, the mysterious, the terrible, are not the only things in history, there is much that is worth while in the story of this commonwealth wherein the peoples of many lands have happily commingled, where varied industries have continuously flourished, where society is peaceful, thrifty and intelligent, where government is orderly, generally efficient, economical, and progressive, where illiteracy is rarely found and education and respect for law are practically universal.

We seriously misjudge onrselves and our past if we concede that there is naught picturesque or dramatic and instructive in our history. In scores of villages and towns throughout the State a Mrs. Gaskell or a George Eliot could find a surfeit of quaint customs, eccentricities in conduct, interesting folk-lore, for studies of local life such as "Cranford" or "Middlemarch." The writer knows two communities where Dickens or Miss Wilkins could find inexhaustible materials for stories of homely life and character; "situations," incidents, problems in heredity, social and religious customs, comedy and tragedy, abound on all sides. To the "special correspondent" who studies our towns and villages from the windows of a flying Pullman, or while he munches a sandwich during the twenty minutes stop for dinner, our local life will be something intolerably dull, flat and unprofitable. But the pulses of life in our villages, while they do not throb and thrill as in the cities and great centers of life and trade, run strong and true; and life may be studied with pleasure and profit here as in Massachusetts or Virginia. The masses of materials simply await the artist's discerning eye and portraying hand.

No one will gainsay this who knows the history of Icaria, the dreams of its founders and the pathos of their failure; or who is familiar with that remarkable communistic community at South Amana. In the quaint and picturesque life at Pella the artist may find his heart's delight. Among the numerous Quaker communities, especially in Cedar county, 
and in the old convent schools here and there in Catholic communities in the older cities of eastern Iowa one may find life and character most interesting. In the traditions of Keosauqua, Keokuk, Fort Madison, Burlington, Muscatine. (Bloomington), Davenport and Dubuque, and others that might be mentioned, the student of life and customs may find much of surpassing interest and instruction.

One needs but to talk with our pioneers concerning early days in Iowa, read their reminiscences in The Annals and The Historical Record, in their letters and occasional memoirs, to realize the wealth of material for fascinating history of the life of a people in one of the favored spots of the continent. Mr. Hamlin Garland's "Boy Life on the Prairies," which so vividly portrays beginnings in our northern farming counties, is an earnest of what picturesque history will some day be written when a Parkman, Fiske, or Eggleston is reared among us and relates the life of the early settlers. The story of the growth of our laws and the institutions of society and of government has as yet been but meagerly told. Our students and scholars have only begun to collect the data.

F. I. H.

\section{AS TO ERRATA.}

It was the intention of the editor of The Annals to present in our last number corrections of various errors in names, dates, etc., which had occurred in the five volumes of the current series. Something was done by way of compiling and correcting these errors, but it was found to be impracticable to carry out the plan in time for that issue. We hope it may be fully accomplished hereafter. While the utmost care is taken in verifying statements and dates in every article, it seems to be an unwelcome but accepted fact, that mistakes will occur, through haste, inadvertence, or by accident. Proofs are sent long distances to authors, but even they often fail to see everything that is printed amiss. Sometimes a pro- 
Copyright of Annals of Iowa is the property of State of Iowa, by \& through the State Historical Society of Iowa and its content may not be copied or emailed to multiple sites or posted to a listserv without the copyright holder's express written permission. However, users may print, download, or email articles for individual use. 